J. WASZKIEWICZ, B. WĘGLORZ

\title{
O PRODUKTACH STRUKTUR DLA LOGIK UOGOLLNIONYCH
}

\section{(Streszczenie)}

W pracy wprowadza się pojęcie logiki tak szerokie, że większość logik badanych obecnie podpada pod to pojęcie. Logiką nazywamy trójkę $\mathfrak{X}=\left\langle X, c_{i}^{\mathfrak{x}}, q_{J}^{\mathfrak{x}}\right\rangle_{\text {icI, jeJ }}$, gdzie $X$ jest niepustym zbiorem, $c_{i}^{\mathfrak{x}}$-skończenie arnymi funkcjami nazywanymi spójnikami, $q_{j}^{\bar{x}}-$ funkcjami z $2^{X}-\{0\} \mathrm{w} X$ nazywanymi kwantyfikatorami. Za pomocą symboli logicznych odpowiadających spójnikom i kwantyfikatorom, predykatów i symboli zmiennych w zwykły sposób buduje się formuły ustalonego języka. Strukturą dla logiki $\mathfrak{X}$ nazywamy parę $\langle\mathfrak{A}, \mathfrak{X}\rangle$, gdzie $\mathfrak{A}=\left\langle A, P_{k}\right\rangle_{k c K}$, gdzie $A$ jest niepustym zbiorem, $P_{k}$ są skończenie arnymi funkcjami z $A \mathrm{w} X$. W prosty sposób uogólnia się pojęcia wartości logicznej, elementarnego zawierania, podstruktury.

W pracy dowodzi się odpowiedników kryterium elementarnego zawierania Tarskiego- Vaughta oraz dolnego twierdzenia Löwenheima-Skolema.

.. Dla takich logik i struktur naturalnym wydaje się pojęcie produktu prostego takie, że $\prod_{r \in R}\left\langle\mathfrak{H}_{r}, \mathfrak{X}_{r}\right\rangle=\left\langle\prod_{r \in R} \mathfrak{A}_{r}, \prod_{r \in R} \mathfrak{X}_{r}\right\rangle$, gdzie $\prod_{r \in R} \mathfrak{A}_{r}$ i $\prod_{r \in R} \mathfrak{X}_{r}$ definiuje się $\mathrm{w}$ zwykly sposób. Okazuje się, że przekątna jest elementarną podstrukturą potęgi prostej. Inne wyniki pracy dotyczą uogólnienia potęgi ograniczonej i produktu zredukowanego.

Idee takiego podejścia do logik i produktów są implicite zawarte w pracy Fefermana i Vaughta [3]. Patrz również Wojciechowska [8]. 